https://doi.org/10.31713/m918

\title{
IMPLEMENTATION OF TECHNOLOGIES FOR CRISIS MANAGEMENT OF ENTERPRISES
}

\author{
Kostrychenko V.M. \\ National University of Water and Environmental Engineering \\ (NUWEE), Ph.D., Associate Professor, Department of Economy of \\ Enterprise, Ukraine
}

Ignatyuk I.Z.

National University of Water and Environmental Engineering (NUWEE), Ph.D., Associate Professor, Institute of Postgraduate Education, Ukraine

\section{Summary}

Modern enterprises operate in the conditions of increased turbulence of the business environment, permanent both positive and negative effects of external and internal factors. The destabilizing effect of certain factors leads to a decrease in the crisis resistance of the enterprise. Therefore, crisis management should be aimed precisely at preventing the enterprise from losing its resilience, preventing or overcoming the crisis of development. To do this, businesses need to have a variety of anti-crisis management technologies.

The subject of the research is theoretical and methodological foundations of introduction of anti-crisis stability management technologies of the enterprise as a process of implementation of anti-crisis procedures applied to a particular enterprise in order to ensure its anti-crisis stability.

The methodology of the research involves reflection of discussion aspects in the interpretation of enterprise crisis resistance, conducting a critical analysis of methodological approaches to its assessment, consideration of a set of basic technologies for managing enterprise crisis resistance, offering synchronization of the type of enterprise crisis resistance and management tools of crisis management technologies.

The purpose of the study is to develop an algorithm for the implementation of management technologies, depending on the level of crisis resistance of the enterprise. The main stages of such an algorithm should be the following: quantitative and qualitative assessment of enterprise crisis resistance, individual selection and implementation of anti-crisis management technologies.

According to the conducted research, active use of various management technologies is required to prevent a decrease in the crisis resistance of the enterprise, as well as to formulate its tactics and strategy for overcoming crisis processes. When choosing anti-crisis management technologies, it is suggested to take into account the stage of the crisis process in accordance with the type of anti-crisis stability of the enterprise and to choose anti-crisis tools that are adequate to these technologies. 


\section{Introduction}

In today's conditions of increased instability and uncertainty of the market environment, the risk for the enterprise to be in crisis is increasing. This is due to the fact that the enterprise as a socioeconomic system develops cyclically against the background of permanent dynamics of the external economic environment. In such circumstances, the role of anti-crisis enterprise management as a systematic process of preventing or overcoming a crisis in order to preserve, restore the pre-crisis state and subsequently improve the potential for successful functioning of the enterprise market, in particular mining industry, is actualized. The need for anti-crisis monitoring of the state of the mining enterprise and the development of its anti-crisis strategy poses the key task of assessing the anti-crisis stability of the enterprise. Particularly acute for enterprises is the problem of choosing and implementing a rational management technology, as well as the skillful use of an arsenal of anti-crisis tools.

Common approaches to the nature and use of anti-crisis management technologies have been studied by domestic and foreign scientists. Theoretical and applied aspects of the problem of economic and anti-crisis resilience, as well as the methodological principles of anticrisis resilience are described in the writings of economists.

At the same time, as numerous studies show, technologies that allow to eliminate the negative manifestations of crises in an enterprise are of high priority in the current practice of crisis management, but they do not provide the conditions for ensuring its crisis resistance. The negative impact of the factors of the economic environment contributes to the increase of crisis processes, which actualizes the study of management technologies in the direction of regulation of crisis resistance of the enterprise.

The purpose of the study is to develop an algorithm for the implementation of management technologies, depending on the level of crisis resistance of the enterprise.

In order to achieve this goal, the following tasks were solved in the research: to consider specific features of sustainable development of mining enterprises; to open up discussion aspects in the interpretation of enterprise crisis resistance; to conduct a critical analysis of methodological approaches to its evaluation; to characterize modern technologies of crisis management of enterprise; to establish compli- 
ance with the type of anti-crisis resilience of the enterprise and tools of anti-crisis management technologies.

The research contains elements of scientific novelty, in particular, the proposed methodological imperatives in the assessment of enterprise crisis resistance, as well as the algorithm of implementation of enterprise crisis management technology.

\section{Setting objectives, the main text}

The functioning of the enterprise in the current market environment is accompanied by the complexity of counteracting the enterprise to different groups of factors. In order to ensure the sustainable development of the enterprise in the long term, its stability must be constantly monitored. The problem of defining and ensuring anticrisis resilience of the enterprise is of particular relevance in a crisis economy and fierce competition in the market, which is characterized by non-deterministic factors of influence.

Mining enterprises are permanently exposed to external and internal factors during their operation. The destabilizing influence of individual factors leads to a decrease in the crisis resistance of these enterprises. Therefore, crisis management should be aimed precisely at preventing the loss of a firm's stability, prevention or overcoming the crisis of development. To do this, there must be a variety of anti-crisis management technologies in the mining enterprise's arsenal. This actualizes the choice of adequate anti-crisis technology of enterprise management, which should depend on the level of economic stability and the direction of its dynamics.

\section{Specific features of sustainable development of mining enter- prises}

In the Ukrainian economy, the mineral resources sector occupies one of the central positions, which determines the high importance of the state of mineral reserves and the dynamics of its development. In Ukraine, which is rich in various minerals, about 90 of their species have been explored and 8,000 fields are being developed. The average level of use of minerals is no more than $15 \%$ of the technologically possible potential; the productivity of labor in the industry is 3 times lower than the level reached in the developed countries. The annual investment in mining is less than $1 \%$ of the revenue it receives $[1, \mathrm{p} .45]$. 
In modern conditions, complex processes of institutional, technological and organizational transformations take place at the mining enterprises. They cover the material and technical base; affect the volume of production and sales of products, economic and financial condition of enterprises. According to the analysis of mining and quarrying indices, the industrial production index in 2016 was $99.8 \%$ compared to 2015 . In 2017, the industry reduced its production volumes by $5.5 \%$ compared to the previous year. The year 2018 was marked by a slight improvement, when the growth rate of production was $102.4 \%$ compared to the previous year. The share of unprofitable enterprises in industry for 2015-2018 was within the range of 27.1-28.2\%. However, the crisis processes currently unfolding in the global and national economies are likely to lead to an increase in the number of unprofitable enterprises. For comparison, in 2010, after the crisis of 2008-2009, this figure reached $41.3 \%$.

Taking into account the specific features of mining enterprises, it is possible to determine the factors that influence their crisis resistance (Table $1)$.

Table 1

Factors of influence on the crisis resistance of mining enterprises

\begin{tabular}{l|l}
\hline $\begin{array}{l}\text { Specificity of the mining } \\
\text { enterprise }\end{array}$ & $\begin{array}{l}\text { Factors of influence on the crisis resistance of the } \\
\text { enterprise }\end{array}$ \\
\hline $\begin{array}{l}\text { 1. Exhaustive reserves of } \\
\text { mineral deposits }\end{array}$ & $\begin{array}{l}\text { - limited life cycle of the enterprise; } \\
\text { - significant costs of liquidation of the enterprise; } \\
\text { - the need for investment in the development of new } \\
\text { fields. }\end{array}$ \\
\hline $\begin{array}{l}\text { 2. The location of the en- } \\
\text { terprise is often in undevel- } \\
\text { oped areas }\end{array}$ & $\begin{array}{l}\text { - significant costs of creating a complete infrastruc- } \\
\text { ture. }\end{array}$ \\
\hline $\begin{array}{l}\text { 3. Release of a monoprod- } \\
\text { uct }\end{array}$ & $\begin{array}{l}\text { - high dependence on market conditions; } \\
\text { - low maneuverability in the range. }\end{array}$ \\
\hline $\begin{array}{l}\text { 4. Information insufficien- } \\
\text { cy of information on min- } \\
\text { ing and technological con- } \\
\text { ditions }\end{array}$ & $\begin{array}{l}\text { - significant costs for further exploration of the field; } \\
\text { - the risk of commercial inefficiency of the project. }\end{array}$ \\
\hline $\begin{array}{l}\text { 5. High capital intensity of } \\
\text { the production process }\end{array}$ & $\begin{array}{l}\text { - significant costs for construction and technical } \\
\text { equipment of the enterprise. }\end{array}$ \\
\hline $\begin{array}{l}\text { 6. Dangerous working con- } \\
\text { ditions }\end{array}$ & - significant costs of safe working conditions. \\
\hline $\begin{array}{l}\text { 7. Significant environmen- } \\
\text { tal impacts of mining }\end{array}$ & $\begin{array}{l}\text { - significant costs of environmental protection and } \\
\text { mitigation measures. }\end{array}$ \\
\hline
\end{tabular}

Source: generated by authors based on materials $[1, \mathrm{p} .47]$ 
At present, the competitiveness and sustainability of most domestic mining companies is ensured by the relatively low cost of consumed energy, material and labor resources, whose prices are on average 4 times lower than the world. In the context of an open economy, it will inevitably equalize the cost of consumed resources to the world level, which will take Ukrainian producers out of competitive production.

The above facts confirm that mining enterprises, by meeting the economic needs at the present stage, threaten the ability to satisfy them in the future, have low rates of development and insufficient level of competitiveness in the world markets, which directly affects the anti-crisis stability of these enterprises.

Under such conditions, mining companies are not only forced to make new technical, technological and organizational decisions that must ensure effective qualitative transformations, but also to introduce modern technologies for managing their anti-crisis stability.

\section{Discussion aspects in the interpretation of enterprise crisis re- sistance}

Review of well-known scientific works on the interpretation of the essence of crisis resistance showed that in modern economic science, this concept is often identified with financial stability. Generalizing the existing interpretations of the concept of "crisis crisis", we can say that the authors, often formulating definitions, often use the following definitions as a basis: it is the ability of the enterprise, it is a complex category, it is a characteristic of the activity or condition of the enterprise, and more. The most common definitions of enterprise crisis resistance are those in which the emphasis is placed on the fact of a crisis situation and decision making on its exit $[2 ; 3 ; 4 ; 5 ; 6]$. According to this approach, anti-crisis resilience is the ability of an object to return to a state of economic equilibrium after it has been withdrawn from that state by the negative effects caused by the crisis [5, p.56]. In continuation of the same approach, another definition can be made: anti-crisis resilience is a characteristic of the internal state of the enterprise and its position in the business space, at a proper level of which in the event of a crisis, the enterprise does not reduce its real value or is able to restore it quickly with minimum costs $[6$, p.324]. 
However, in our opinion, companies that focus on preventive crisis management in the context of permanent changes and uncertain economic environment demonstrate that crisis is resilient. It is this understanding of the crisis resistance of the enterprise formulated in scientific works $[7 ; 8 ; 9]$. Noteworthy is the interpretation of crisis resistance as the ability of an enterprise to prevent the cardinal impact of the crisis on its financial and economic activities through the use of anti-crisis management technology, taking into account the specifics of the industry and the formation of reserve funds during the phase of lifting the life cycle of the enterprise [9, p.6]. According to this approach, anti-crisis resilience is the ability of an enterprise to withstand crisis influences, and in the event of a crisis, to restore the pre-crisis state in the shortest possible time; anti-crisis resilience is a target function of enterprise management for crisis prevention [8, p.51]. Undoubtedly, the prevention of the negative impact of environmental factors, as well as the obligatory formation of reserve funds in enterprises in order to insure against possible unforeseen circumstances is an indispensable condition for its anti-crisis stability [7, p.38].

Summarizing the scientific views on this category, in our opinion, the anti-crisis stability of the enterprise can be interpreted as such a characteristic of the internal state of the enterprise and its position in the external economic environment, at a proper level of which the enterprise is able to prevent a crisis situation, and in the event of its occurrence can quickly to recover its real value by maneuvering available resources and making crisis decisions.

\section{Methodical approaches to assessing the crisis resistance of an enterprise}

Crisis resilience of the enterprise plays an important role in ensuring the long-term functioning and effective development of the enterprise in the face of challenges produced by the competitive environment, uncertainty and threat of crisis situations. Therefore, there is a need for permanent evaluation of crisis resistance in order to make rational decisions on the functioning and development of the enterprise, which will allow to achieve the set strategic goal and the desired result with minimal negative consequences.

Anti-crisis resilience assessment is a set of actions that allow to establish the level, dynamics and tendencies of change of indicators characterizing the results of the enterprise activity, that is, it provides 
for the interpretation of indicators describing the economic phenomenon. Exploring the methodological principles of anti-crisis resilience assessment, scientists propose different scientific approaches, which explains the existence of alternative methods and different methods of appropriate assessment.

Summarizing the scientific debate on the evaluation of economic and anti-crisis sustainability of the enterprise, we have proposed methodological imperatives that can be formulated in this way [10, p.104]: first, methods for assessing anti-crisis stability need to adapt to the peculiarities of functioning in conditions of transformational economic environment; second, anti-crisis resilience studies should be conducted using analytical and evaluation procedures; thirdly, they need to distinguish the anti-crisis resilience subsystems, which are associated with the provision of certain areas of activity of the enterprise; fourthly, a rational system of assessment of the anti-crisis stability of the enterprise should be formed; Fifth, a quantitative and qualitative assessment of the level of the enterprise's anti-crisis resilience indicator should be carried out; sixth, a certain type of anti-crisis resilience should identify the stage of the crisis process, which will allow to rationalize the anti-crisis tools of the enterprise.

Critical analysis of existing methods for assessing the crisis resistance of the enterprise $[2 ; 3 ; 4 ; 11 ; 12]$ showed that there are different visions of such calculations in the scientific environment. The authors propose different principles of construction of the methodology, the list of components of the crisis stability of the enterprise and a set of indicators of crisis resistance of the enterprise, in which the systematic reflection of external and internal, financial and nonfinancial indicators is not always present.

In our opinion, the best way to evaluate the crisis response of an enterprise can be built on the basis of a comprehensive approach and taking into account the principles of forming a balanced scorecard. Such a system is a strategic planning and management tool that serves to set strategic goals and evaluate the effectiveness of an enterprise from the point of view of strategy implementation with the help of certain key performance indicators [13, p.247]. The scorecard itself is formed in the context of four projections: finance, customers, internal business processes, training and staff development. Based on this approach, we have proposed a system of indicators for evaluating the 
crisis resistance of the enterprise, combined, according to projections, within the following functional components: financial, marketing, operational, investment-innovation, management and information, personnel.

An enterprise, having information on the level and dynamics of anti-crisis stability, can decide on the configuration of technological schemes of anti-crisis management.

\section{Modern technologies for crisis management of enterprise}

Broadly speaking, technology is a set of actions or sets of operations that are used in various fields. Management technology is a constant creative process of maintaining a sustainable mode of functioning of the economic system by making and implementing economic decisions. At some stage of evolution, technology was seen as information and means of storing it, as activity and knowledge about cause and effect, as the variability of resources and processes of search [14, p.58].

The meaningful content of the concept of "control technology" can be revealed using content analysis. It is by the results of such a study [15] that a general definition was formulated: management technology is a purposeful, orderly, coordinated set of management procedures that are implemented within management functions and provided with a choice of appropriate management tools and methods [15, p.74].

In Western management there are three main groups of technologies: technologies of planning of management decisions; technologies of implementation of management decisions; technologies for changing the structure of the organization. In our country, the most common way is thematic-sectorial grouping of technologies by relevant sections of management (strategic management, personnel management, business process management, logistics management, etc.), by management functions (planning, organization, motivation, control), or by major management perspectives (finance, customers, internal processes, training and development) [16].

The analysis of the application of management technologies in economics and finance shows that today the priorities are shifting in the direction of transition from special management technologies to complex self-replicating ones. Integrated technology for managing financial and economic processes is a set of purposeful, hierarchically 
ordered, coordinated in time and resources, rational management procedures that correspond to the state of the external and internal environment of the economic entity and are implemented within the range of management functions through the use of management tools [17, p.327].

The following features are inherent in the complex technology of financial and economic process management: strategic orientation; extensive composition of procedures; dependence of the content of management procedures on the phase of economic entity development; coverage of several management functions; requirements for high competence of personnel for the use of complex technology [17, p.327]. The above specificity confirms the possibility of using such technologies in crisis management of the enterprise.

Anti-crisis management technology means a set of sequential measures taken to prevent, prevent, overcome a crisis and reduce the level of negative consequences of its implementation. It demonstrates the peculiarities of the behavior of the management subject in a crisis situation, reflecting the patterns and specifics of the choice and implementation of a certain sequence and interrelation of operations on the development of anti-crisis solutions [18, p.382].

All anti-crisis management technologies can be grouped into the following active, reactive and predictive anti-crisis management technologies. A concise description of these technologies is shown in Table 2.

Table 2

The set of anti-crisis management technologies

\begin{tabular}{l|l}
\hline Technology groups & Intrinsic characteristic of technology \\
\hline \multirow{2}{*}{$\begin{array}{l}\text { Active management } \\
\text { technology }\end{array}$} & $\begin{array}{l}\text { It assumes the transition to action when the threshold of } \\
\text { rational understanding of the threat of crisis phenomena is } \\
\text { reached and to determine on this basis the nature of } \\
\text { emerging problems, selection and testing according to the } \\
\text { criteria of strategic development of the most acceptable } \\
\text { options for operational response to emerging threats. }\end{array}$ \\
\hline \multirow{2}{*}{$\begin{array}{l}\text { Jet control technolo- } \\
\text { gy }\end{array}$} & $\begin{array}{l}\text { management object is low and strategic discrete deviations } \\
\text { from the established trends are rare; at the initial stage of } \\
\text { response to a threat, an idea of the nature of the problem is } \\
\text { formed and a consistent strategic response is made in the } \\
\text { form of an attempt to apply operational measures, saving } \\
\text { resources. }\end{array}$ \\
\hline
\end{tabular}


Continuation of table. 2

\begin{tabular}{lc|l}
\hline $\begin{array}{l}\text { Predictable crisis } \\
\text { management } \\
\text { nology }\end{array}$ & $\begin{array}{l}\text { Built on the pre-emptive action before a crisis threat, on } \\
\text { recognizing the nature of the threat and selecting options } \\
\text { for combining strategic and operational responses; based } \\
\text { on forecasting, which allows the company to take the nec- } \\
\text { essary steps before a possible threat can cause enough } \\
\text { tangible damage to the enterprise. }\end{array}$ \\
\hline
\end{tabular}

Source: Authored by authors [18].

The modern arsenal of control technologies has a significant number of their types depending on the degree of centralization, the order of operations and procedures, the degree of division of labor, object, subject, functional orientation, the level of automation, structuring of the control object, the level of control [17, p. 325].

In summary, the composition of technologies used in economic management and the main types of crisis management technologies for economic processes are shown in table 3.

Table 3

Modern anti-crisis technologies of economic process management

\begin{tabular}{l|l}
\hline $\begin{array}{l}\text { Technologies used in economic } \\
\text { management }\end{array}$ & $\begin{array}{l}\text { The main types of crisis management technol- } \\
\text { ogies for economic processes }\end{array}$ \\
\hline Strategic Management & Customer Relationship Management (CRM) \\
Business Planning & Benchmarking \\
Marketing Management & Strategic planning \\
Financial Management & Outsourcing \\
HR & Balanced Scorecard (BSC) \\
Corporate Governance & Controlling \\
Quality management & Change management \\
Information Technology & Key competencies management \\
Operational management & Business Process Reengineering \\
Production management & Consumer segmentation \\
Logistics technologies & Quality management \\
Structuring and organization of \\
business processes & Loyalty management \\
\hline
\end{tabular}

Source: generated by the authors on materials [14, p.64-65; 17, pp.324-325; 19].

The monitoring of the implementation and use of various management technologies, which has been conducted for a long time by the consulting company Bain \& Company, showed the level of popularity and effectiveness of the use of management practices. The most widely used management technologies in the world are customer relationship management, benchmarking, employee engagement surveys, 
strategic planning, outsourcing, a balanced scorecard, mission and vision development [19].

In domestic practice, the high level of use has the tools of customer relationship management (66.7\% of respondents) and budgeting technology (70.6\%) [20, p.153]. This indicates an active search for methods of enterprise adaptation by domestic management, identification of new sources for obtaining competitive advantages and directions of development of Ukrainian business.

At the same time, Ukrainian enterprises are under-utilizing the management technologies of innovative management. In particular, only $39 \%$ of respondents admit that their businesses have innovation management, $31 \%$ - benchmarking, 32\% - knowledge management, $22.5 \%$ - change management, $21 \%$ - scenario planning. In the conditions of turbulent changes of the external and internal environment, the tasks of development and implementation of management technologies are actualized, which requires constant benchmarking, scenario planning and systematic change management [20, p.154-155].

The dynamic changes that take place in the business environment require the use of management technologies that are capable of ensuring the anti-crisis stability of the economic system.

\section{The algorithm of introduction of technologies of crisis man- agement of enterprise}

Management of crisis resistance of the enterprise involves the construction of appropriate technological schemes of crisis management. Therefore, management technology involves an orderly sequence of implementation of a set of certain operations in the development and use of anti-crisis tools. In the process of such activity, it is important not only to choose the management technologies that best meet the nature of the problems, the level and type of crisis resistance of the enterprise, but also to ensure their implementation.

The description of the steps in our proposed algorithm allows us to demonstrate the procedural features of the implementation of anticrisis management technologies of the enterprise (Table 4).

Modern methodological approaches to the process of establishing the level of anti-crisis stability should take into account that the procedures for the study of anti-crisis stability of the enterprise are divided into two groups, namely: analytical and evaluation. Analytical procedures involve the use of such economic tools that can quantify 
the level of crisis resistance of the enterprise. Evaluation procedures provide a qualitative assessment and compliance with the level of the overall integral index of anti-crisis firm stability of the Harrington scale, as well as determining the type of anti-crisis stability [21, p.60].

Table 4

An algorithm for the introduction of anti-crisis resilience management technologies

\begin{tabular}{|c|c|}
\hline Stage & Contents of the stage \\
\hline $\begin{array}{l}\text { Step 1. Quantification } \\
\text { of ACP }\end{array}$ & $\begin{array}{l}\text { 1. Definition of ASP subsystems (components). } \\
\text { 2. Formation of a system of estimates. } \\
\text { 3. Calculation of individual indicators of the ASA, } \\
\text { their evaluation and standardization. } \\
\text { 4. Determination of the weight of single and key per- } \\
\text { formance indicators in ASA subsystems. } \\
\text { 5.Calculation of key performance indicators for each } \\
\text { subsystem and their interpretation. } \\
\text { 6. Calculation of the integral indicator of the ASA. }\end{array}$ \\
\hline $\begin{array}{l}\text { Step 2. Qualitative as- } \\
\text { sessment of the UAV }\end{array}$ & $\begin{array}{l}\text { 1. Establishment of compliance with the level of the } \\
\text { overall integral index of the FAS of the Harrington } \\
\text { scale. } \\
\text { 2. Determination of the type of ASP. }\end{array}$ \\
\hline $\begin{array}{l}\text { Step 3. Synchronization } \\
\text { of the type of ACP and } \\
\text { solutions in crisis man- } \\
\text { agement technologies }\end{array}$ & $\begin{array}{l}\text { 1. Identification of the stage of the crisis process ac- } \\
\text { cording to the type of ASA. } \\
2 \text {. Establishing an appropriate type of crisis manage- } \\
\text { ment. }\end{array}$ \\
\hline $\begin{array}{l}\text { Step 4. Individual selec- } \\
\text { tion of crisis manage- } \\
\text { ment technologies }\end{array}$ & $\begin{array}{l}\text { 1. Formation of a set of anti-crisis technologies of } \\
\text { enterprise management. } \\
\text { 2. The choice of management technologies, depending } \\
\text { on the level of ASP. }\end{array}$ \\
\hline $\begin{array}{l}\text { Step 5. Implementation } \\
\text { of ASA management } \\
\text { technologies }\end{array}$ & $\begin{array}{l}\text { 1. Creation of a system of information and intellectual } \\
\text { support for crisis management of the enterprise. } \\
\text { 2. Arrangement of anti-crisis tools for providing the } \\
\text { ASA. } \\
\text { 3. Implementation of ASA management technology. } \\
\text { 4. Evaluation of the effectiveness of the implementa- } \\
\text { tion of the control technology of the ASA. }\end{array}$ \\
\hline
\end{tabular}

Source: Developed by the authors

The evaluation process does not end with the calculation of the overall integral indicator of the enterprise's crisis resistance. Next, the compliance with the indicator level of a certain stage of the crisis process, which determines the type of crisis management [22, p.230] (table 5). 
Table 5

Compliance with the type of anti-crisis stability of the enterprise type of anticrisis management

\begin{tabular}{l|l|l}
\hline \multicolumn{1}{c|}{ Type of crisis resistance } & Stage of the crisis process & \multicolumn{1}{|c}{$\begin{array}{c}\text { Type of crisis } \\
\text { management }\end{array}$} \\
\hline Absolutely & Crisis phenomenon & Preventive \\
\hline Enough & The crisis situation & Wellness \\
\hline Unstable economic condition & Pre-crisis state & Stabilization \\
\hline Low & Crisis & Rehabilitation \\
\hline Catastrophic & Crisis & Liquidation \\
\hline
\end{tabular}

Source: Developed by the authors

The above identification creates the basis for the application of rational anti-crisis management technologies and making effective business decisions by the enterprise (Table 6). Given that the crisis process in the enterprise is able to move from individual crisis phenomena to a crisis situation, which can develop into a crisis state, in the practice of crisis management, different methods can be used both in relation to individual parameters of the crisis phenomenon and in relation to the crisis situation as a whole [22, p.231].

Tactical and strategic methods are used in managing the crisis resistance of the enterprise. Tactical methods, including downsizing, remediation, monitoring, controlling, are aimed at rapid improvement of financial performance of the enterprise, ie overcoming the consequences of the crisis. However, in most cases these methods are not sufficient to address the root cause of the crisis - an inefficient management system. This requires the use of longer-term strategic measures, such as diversification, regularization, reengineering, restructuring, mergers, liquidation, which are aimed at improving the quality characteristics of enterprises [23, p.118-119].

Table 6

Solutions developed within the framework of anti-crisis technologies

\begin{tabular}{l|l}
\hline \multicolumn{1}{c|}{ Type of crisis resistance } & \multicolumn{1}{c}{ Contents of anti-crisis solutions } \\
\hline Absolutely & $\begin{array}{l}\text { aimed at ensuring crisis resistance and preventing } \\
\text { the emergence of crisis phenomena, as well as fur- } \\
\text { ther development of the enterprise }\end{array}$ \\
\hline Enough & $\begin{array}{l}\text { aimed at restoring anti-crisis stability and preventing } \\
\text { the emergence of crisis situations at the enterprise }\end{array}$ \\
\hline $\begin{array}{l}\text { Unstable economic condi- } \\
\text { tion }\end{array}$ & $\begin{array}{l}\text { aimed at stabilizing the enterprise and avoiding } \\
\text { bankruptcy proceedings }\end{array}$ \\
\hline
\end{tabular}


Continuation of table. 6

\begin{tabular}{l|l}
\hline Low & $\begin{array}{l}\text { aimed at withdrawing a company from a crisis state, } \\
\text { achieving a pre-crisis state; aimed at minimizing the } \\
\text { negative effects of the crisis, preventing the liquida- } \\
\text { tion of the enterprise }\end{array}$ \\
\hline Catastrophic & $\begin{array}{l}\text { are directed to proceed with the procedure for liqui- } \\
\text { dation of the company against which the bankruptcy } \\
\text { case is initiated }\end{array}$ \\
\hline
\end{tabular}

Source: Developed by the authors

In the process of crisis management of the enterprise there is a problem of making complex management decisions and not only the choice but also the introduction of the most effective management technology. This necessitates the use of information technologies capable of enhancing the intellectual level of the decisions being made, their timeliness and adequacy. It is necessary to take into account the peculiarities of using information technologies in accordance with the types of crisis management.

Creation of information-intellectual support system for crisis management of the enterprise enables the managers of the enterprise to effectively manage certain areas of activity of the enterprise, to coordinate the activities of structural units, quickly find information about changes in the internal state of the enterprise and changes occurring in the external environment, to track trends, to have them, comfortable display, and evaluate the effectiveness of management decisions made in the environment withdrawal of the enterprise from crisis [24, p.142-143].

Determining the selection and application of anti-crisis technologies for managing the anti-crisis stability of the enterprise is a careful selection and justification of practical anti-crisis tools. Combining anti-crisis solutions can be different, given the type of anti-crisis stability and the corresponding stage of the crisis process [22, p.231].

Loss of anti-crisis stability by the enterprise necessitates the development and implementation of a set of strategic, tactical and operational economic decisions. At each stage of the crisis process, it is necessary to choose the dominant individual anti-crisis solutions or a combination of them, which will ensure rapid recovery of anti-crisis stability or minimize the negative consequences of the crisis [22, p.231]. 
Strategic managerial decisions include drastic restructuring at the enterprise, change of directions of financial flows into product groups or target segments, transformation of structure, entry into new regional markets, expansion or reduction of activity, change of assortment policy [22, p.231].

Tactical management decisions are related to the development of new models of enterprise behavior in the market, change in pricing policy, organization of promotions, updating of material and technical base, optimization of work of the team, etc. Operational management decisions are made in the process of daily work of the labor collective and are related to the organization of work of direct executors, providing them with resources, front of work, information [22, p.231].

However, most Ukrainian businesses in management practice are focused on monetary (financial) business valuations. This indicates a low level of strategic orientation of enterprises, the desire to focus activities on achieving acceptable levels of short-term financial indicators (in particular, profit, sales). As a result, there is an insufficient use of modern anti-crisis management technologies by domestic enterprises.

\section{Conclusions}

1. In today's conditions of increased turbulence of the economic environment, the increase of negative processes in the functioning of industrial enterprises increases the threat for them to be in crisis. Given the current economic trends and specific features of mining companies, it is possible to predict the gradual loss of their anti-crisis stability.

2. Crisis resistance of the enterprise can be interpreted as such a characteristic of the internal state of the enterprise and its position in the external economic environment, at a proper level of which the enterprise is able to prevent a crisis situation, and in case of its occurrence can quickly recover its real value, maneuvering available resources and accepting anti-crisis solutions.

3. The methodology for assessing the crisis crisis of the enterprise is based on a balanced scorecard, which is formed in the context of four projections: finance, customers, internal business processes, training and staff development. In the system we offer, the indicators of anti-crisis resilience assessment of the enterprise are combined, 
according to projections, within the following functional components: financial, marketing, operational, investment-innovative, managementinformational, personnel.

4. The overall level of application by Ukrainian enterprises of modern anti-crisis management technologies remains relatively low. The problem remains with the use of information and virtual technologies by the enterprises of crisis management, which are able to increase the intellectual level of the decisions made.

5. The introduction of anti-crisis resilience management technologies of the enterprise should be carried out according to the appropriate algorithm, which provides for individual selection of anti-crisis management technologies. This should take into account the stage of the crisis process in accordance with the type of anti-crisis resilience of the enterprise and select anticrisis tools that are adequate to these technologies.

In the future, the scientific and practical interest is the development of anti-crisis strategies and the design of technological management schemes, taking into account the level of anti-crisis stability of the enterprise and possible scenarios for its change.

\section{References}

1. Shapoval V.M, Gerasimenko T.V. Management of socio-economic development of the mining enterprise. Innovative economy. No. 5-6 (63). 2016. P.45-50.

2. Dzherelyuk Yu.O. Analysis of components of providing external and internal anti-crisis stability of tourist enterprises. Business Inform, 2018. № 3. P.364-370. URL: http: // business-inform-2018__3_0 pages 364_370 pdf (accessed 20/04/2020).

3. Kostina O.M. A system of indicators for assessing the crisis resistance of an industrial enterprise. URL: http://repository.hneu.edu.ua> bitstream> (accessed: 04/20/2020).

4. Koyuda V.A., Kostina O.M. Directions and components of industrial crisis anti-crisis resilience assessment. Theoretical and practical aspects of economics and intellectual property. 2015. Vol. 2 (12). Vol. 2, pp. 39-47. URL: http://nbuv.gov.ua/UJRN/Tpaeiv_2015_2(2)__8 (accessed: 04/20/2020).

5. M. Laktionov, A. Zub. The theory and practice of crisis management. Moscow: Genesis, 2005. 576 p.

6. Freedom T.I. Theoretical prerequisites for the formation of an anti-crisis strategy of a trading company. Economic strategy and prospects for development of trade and services. 2009. Iss. 2. P. 322-329. URL: http://nbuv.gov.ua/UJRN/esprstp_2009_2_48 (accessed: 04/20/2020).

7. Grosul V.A., Zhilyakova O.V. Mechanism of crisis management of enterprise on the basis of cognitive modeling methodology. Economic efficiency of business in the conditions of an unstable economy: Collective Monograph - Aspect Publishing, Taunton, MA, United States of America, 2015. 332 p. P.37-45. 
8. V.A. Rogova Concept and stages of crisis management of organizations. JURSTU Bulletin (NPI), 2012. № 1. P. 51-55.

9. L.V. Uryvskaya Increasing the anti-crisis resilience of agricultural enterprises in the system of state regulation of agroindustrial complex: author. diss. ... Cand. econom. Sciences: 08.00.05. Moscow, 2010. 20 p.

10. Kostrychenko V., Kravtsiv M. Methodical imperatives in estimating the economic stability of an enterprise. International Journal of New Economics, Public Administration and Law. Varna-Świnoujście, 2018. № 1 (1). P. 101-111.

11. Dzherelyuk Yu.O. Assessment of internal crisis resistance of tourism enterprise. Global and national problems of the economy. 2018. Vip. 21. URL: http://global-national.in.ua/issue-21-2018 (accessed: 04/20/2020).

12. Chicken S.T. Methodology of crisis management of economic stability of aviation enterprises: dis. ... Dr. Econ. Sciences: 08.00.04. Kyiv, 2014. 791 p.

13. Kaplan Robert S., Norton David P. A Balanced Scorecard. From strategy to action / trans. with English. 2nd ed. and ext. Moscow: Olympus-Business, 2004. $320 \mathrm{p}$.

14. Sofronova O.B. Adaptation of foreign management technologies in Russian companies. SPbSU Newsletter, Ser. 8. 2005. Issue. 2 (No. 16). Pp. 57-72.

15. Chmutova I.M. The essence of management technology and its key features. Scientific Bulletin of Chernivtsi University. Avg. Economy. Chernivtsi, 2014. Vol. 710-711. C. 70-75.

16. Nechaev I.A., Kabak M.V. Features of enterprise management based on the use of modern technologies and management systems. Effective Economy, 2017. \# 9. URL: http://www.economy.nayka.com.ua/?op=1\&z=5771 (accessed 20/04/2020).

17. Chmutova I.M., Andriychenko J.O., Dovgopol Y.S. Evolution and modern tendencies of development of technologies of management of financial and economic processes. Economy and society. 2017. №11. P.322-329.

18. Korotkov E.M. Crisis management: a textbook for bachelors. Moscow: Yurite, 2016. 406. URL: https://stud.com.ua/48517/ekonomika/antikrizove_upravlinnya (accessed: 04/20/2020).

19. Management Tools \& Trends 2015 / Bain \& Company, 2015.URL: https://www.bain.com/insights/management-tools-and-trends-2015(turned: 04/20/2020).

20. Willow V.A. Evolution of management technologies as a reflection of problems and tasks of enterprise development. Economic Development Strategy of Ukraine. 2014, No. 34, pp. 148-156.

21. V. Kostrichenko, V. Kovalchuk. Evaluation of enterprise crisis resistance: methodological aspects. Notes of the VI Taurida National University Vernadsky. Series: Economics and Management. Volume 30 (69). N 5. Part 2, 2019. P.57 - 63.

22. Kostrichenko V.M. Crisis management technologies of economic stability of the enterprise. Theory, methodology and practice of economic and financial activity of enterprises: a collective monograph / Qty. authors. Poltava: PE "Astraia", 2019. P.227-232.

23. Kovalevskaya A.V. Enterprise crisis management: lecture notes. Kharkiv: KhNUMG them. OM Beketova, 2016. 140 p.

24. Ramazanov S.K., Stepanenko O.P., Timashova L.A. Anti-crisis management technologies. Monograph. Lugansk: View of SNU them. V. Dahl, 2004. 192 p. 